\title{
Human urinary amylolytic enzymes in acute hepatitis
}

\author{
C. FRANZINI AND S. MODA \\ From the Laboratory of Clinical Investigations and Department of Medicine, \\ the Civic Hospital of S. Antonio Abate, Gallarate, Italy
}

SYNPOSIS Using paper eletrophoresis two amylolytic enzymes in human urine were demonstrated. A main peak was shown in the gamma globulin zone in normal urine and a second minor peak, in contrast to earlier findings, in the beta globulin zone. The organic source of the minor peak is probably in the liver. Urines from cases of acute hepatitis were studied in the same way and showed that the electrophoretic beta peak was raised in acute hepatitis, also pointing to a possible origin in the liver. Further studies are required to confirm this hypothesis.

Evidence has been obtained in this laboratory demonstrating two amylolytic enzymes in human urine, differing both for electrophoretic mobility (Franzini, 1965a) and for elution volume from Sephadex columns (Franzini, 1965b), this latter feature indicating a difference in molecular weight.

In common with other workers (Wilding, 1963; Delcourt, Delcourt, and Wettendorff, 1964) we found that when urine is fractionated by means of paper electrophoresis a main peak of amylolytic activity is found in the gamma globulin zone, accounting in normal urine for about 97 to $98 \%$ of total activity. Indirect evidence has also been reported indicating that in this main peak the urinary amylase was of pancreatic origin (Franzini, 1965a); this is consistent with the data in the literature concerning amylase in electrophoretic fractions of human serum (Baker and Pellegrino, 1954; McGeachin and Lewis, 1959; Dreiling, Janowitz, and Josephberg, 1963; Wilding, 1963; Delcourt et al., 1964; Searcy, Ujihira, Hayashi, and Berk, 1964); amylase of salivary origin too is reported to exhibit a gamma mobility on paper electrophoresis (McGeachin and Lewis, 1959).

The occurrence of the second minor, peak of amylolytic activity is, on the contrary, in apparent contrast to former results; it shows a beta globulin mobility and accounts, in normal urine, for about 2 to $3 \%$ of total activity. The origin as well as the possible physiological or pathological role of this enzyme is, at present, obscure.

The organic source of the minor peak of urinary amylase is probably in the liver. Although early workers denied the existence of any intracellular hepatic amylase (Somogyi, 1941), the occurrence of such an enzyme has recently been demonstrated (McGeachin and Potter, 1960; Brosemer and Rutter, 1961 ; Olavarriia and Torres, 1962); moreover several

Received for publication 26 August 1965. starch-splitting enzymes are found in the liver (Torres and Olavarriia, 1964; Rosenfeld, 1964). As a first approach to this problem and to search for a possible pathological explanation of this urinary enzyme, the electrophoretic behaviour of urinary amylolytic enzymes in acute hepatitis was investigated.

Twenty-four hour urine specimens were obtained from normal males and from subjects suffering from acute hepatitits, whose diagnoses had been established through adequate clinical investigations. The urines were concentrated, submitted to electrophoretic separation, and amylase was quantitated, at $p \mathrm{H} 7$, in the electrophoretic fractions as outlined previously (Franzini, 1965a).

The results are shown in Table $I$, in which the amylolytic activities in the two peaks are calculated as percentages of the total activity recovered. When expressed in absolute units, i.e., as micromoles maltose $/ 1 \mathrm{ml} . / 60 \mathrm{~min}$., the activities of the beta peaks from hepatitis urines were higher than the corresponding peaks from normal urines; the activities of the gamma peaks from both normal and hepatitis urine were, on the contrary, roughly of the same size.

\section{TABLE I}

DISTRIBUTION OF URINARY AMYLOLYTIC ACTIVITY (AS PERCENTAGE OF TOTAL RECOVERED) BETWEEN THE TWO ELECTROPHORETIC PEAKS

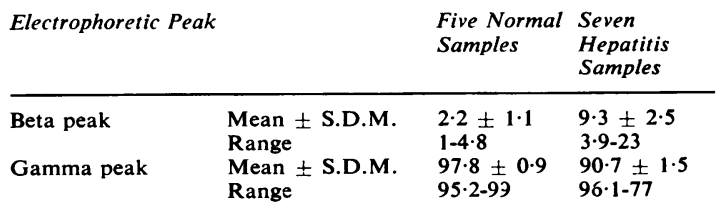

The data show that the electrophoretic beta peak of urinary amylolytic activity was raised in acute hepatitis: this seems to be due to an effective increase 
of this enzyme rather than to a concomitant decrease of the enzyme with gamma mobility.

The incomplete recovery of enzymic activity from the electrophoretic strip (Franzini, 1965a) may be an important drawback in interpreting the present data, probably due to inactivation of the enzymes by heat during the electrophoretic migration. However, since the same technique was applied to both normal and pathological samples, the results seem to point to a possible origin of the enzyme with beta mobility in the liver. It is well known that several liver enzymes are released as a result of serious cell injury.

On the other hand it must be taken into consideration that other organs, e.g., the kidney, may be compromised in the course of hepatitis, and further studies are necessary to investigate this important aspect of the problem. Experiments are now in progress in our laboratory in order to define the biochemical nature of the beta-peak enzyme and possibly, its organic source.

\section{REFERENCES}

Baker, R. W. R., and Pellegrino, C. (1954). Scand. J. clin. Lab. Invest., $6,94$.

Brosemer, R. W., and Rutter, W. J. (1961). J. biol. Chem., 236, 1253. ®

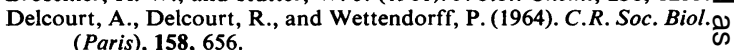

Dreiling, D. A., Janowitz, H. D., and Josephberg, L. J. (1963). Ann. $\vec{\circ}$ intern. Med., 58, 235.

Franzini, C. (1965a). J. clin. Path., 18, 664.

- (1965b). Biochim. appl. (Parma), 12, 101

McGeachin, R. L., and Lewis, J. P. (1959). J. biol. Chem., 234, 795.

- , and Potter, B. A. (1960). Ibid., 235, 1354.

Olavarriia, J. M., and Torres, H. N. (1962). Ibid., 237.1746.

Rosenfeld, E. L. (1964). In Control of Glycogen Metabolism. (CibaFoundation Symposium), edited by W. J. Whelan and M. P. Cameron, pp. 176-189. Churchill, London.

Searcy, R. L., Ujihira, I., Hayashi, S., and Berk, J. E. (1964). Clin. V chim. Acta, 9, 505.

Somogyi, M. (1941). Arch. intern. Med., 67, 665.

Torres, H. N., and Olavarriia, J. M. (1964). J. biol. Chem., 239, 2427. 을

Wilding, P. (1963). Clin. chim. Acta, 8, 918. 